\title{
Language Games and Their Impact on the Development of Reading Skills among Non-Native Speakers of Arabic Language: An Analytical Study
}

\author{
Ibrahim ALRababah ${ }^{1}$ \\ ${ }^{1}$ Language Center, University of Jordan, Jordan \\ Correspondence: Language Center, University of Jordan, Jordan. E-mail: Rababah80@gmail.com
}

Received: January 14, 2019

Accepted: January 25, 2019

Online Published: February 20, 2019

doi:10.5539/mas.v13n3p23

URL: https://doi.org/10.5539/mas.v13n3p23

\begin{abstract}
The aim of this study is to find out the effect of the use of language games in the development of reading skills among non-native Arabic language speakers. The study has consisted of 40 learners from the beginner level at the Language Center / University of Jordan. The participants were divided into two groups: experimental group which were taught using the strategy of language games and a control group taught using the normal method. To fulfill the purpose of the study, the researcher prepared a test to measure reading skills, and to verify the validity and stability of the test. After doing all the necessary processing and analyzing procedures, the results of the study showed that there were statistically significant differences at the level of significance $(a=00.5)$ for the experimental group. This indicates the positive effect of learning using language games in reading skills. Whereas, There were no statistically significant differences at the level of significance $(a=00.5)$ in the development of reading skills among non-speaking Arabic language learners attributed to gender (male, female). Therefore, the researcher recommended the need to use the strategy of language games for the development of reading skills among non-speaking Arabic language learners.
\end{abstract}

Keywords: language games, reading skills, Arabic language teachers for non-speakers

\section{Introduction}

\subsection{Introduce the Problem}

In light of the current developments, rapid changes and modern technological developments in the field of education in general and in the field of teaching Arabic language to non-Arabic speakers in particular, it is imperative for those who teach language to think about development, rehabilitation and modernization and to find modern teaching methods that keeps abreast of rapid developments and suit the environment surrounding learners. Especially as the teaching methods represent the heart and soul of the learner and the guarantor of development and progress of societies so that they are able to cope with scientific revolutions and keep up with them.

However, the relationship between language and modern technological developments must be a functional and an integrative relationship based on consistency, coherence and harmony between them. In particular, the "Arabic language is a utensil for a global culture with borders so wide and the expression of a great civilization whose influence have spread throughout the globe, as a tool for conveying a general conclusive message, and as a means of performing its rites, proclaiming its words and formulating its principles and systems" (Habibullah, 2000, p34).

"The Arabic language is the most powerful language in adapting to human feelings, cultures and civilizations. It is also the supreme leader of languages in the world for its ability to absorb scientific ideas, concepts and terminology. It has become a prominent entity on the map of human knowledge for its close relationship with the various branches of such knowledge; because it is the vessel of science and human knowledge and the pillar of natural science" (Hussein, 1999, p 57).

In spite of the characteristics of the Arabic language and its aforementioned features and the pride it carries within, whether faithful, scientific, historical or graphic, even economic and political or social,it is facing challenges at various levels, such as the trembling ofits linguistic personality which is a trembling of its entire existence. Unfortunately, the Arabic language is suffering from these shivers caused by the challenges it is facing. Therefore, it is necessary to confront these challenges and intensify the efforts, plans and paying more attention to Read, audio 
and video programs responsible of teaching Arabic language to non-Arabic speakers, study the interests of nonspeakers and their purposes of learning the language and the Arab and Islamic culture and to review the cultural content it provides. Because of the importance of the Arabic language, more attention should be paid to the curricula and to books provided to this segment to achieve their purposes, as well as the teaching methods that focuses on the learner and consider it the center of the educational process and takes into account individual differences and special categories and strengthen the status of educational tools and advanced educational activities in teaching Arabic language to non-speakers.

In light of the previous views and previous aspirations presented and stressed on the need to face the challenges and think about plans and visions and methods of teaching in modern technological means, not to mention the large number of complaints and resentment on the methods used in teaching Arabic to non-speakers, the idea of using language games in teaching of Arabic non-speakers emerged as one of the modern teaching methods that may help overcoming many educational obstacles in the field of teaching Arabic to other speakers.

\subsection{Research Problem}

The field of language learning is undergoing a general reform movement that included many aspects of the educational learning process in order to develop its outcomes and enable learners to contribute in building the process of education and knowledge, keeping abreast of technological developments and the ability to make use of them in the educational process. These technological developments are considered an actual challenge to the curricula and to teaching methods used in education, as well as a real motivation for the development and interpretation of teaching methods and a target to introduce in education. Therefore, it is imperative that universities and educational institutions keep abreast of technological developments, especially as they are still facing many challenges to achieve the desired goals. In order to achieve these goals, it is necessary to identify the challenges facing the field of language education in general and the field of teaching Arabic speakers especially in light of modern technological developments, especially since there are many difficulties and problems facing the teaching of Arabic language to non-speakers in our institutes and educational centers, and this is what the researcher had noted during teaching Arabic language to non-speakers and the weakness of the methods of teaching used and the lack of modern teaching methods for non-speakers which contribute to their training and the practice of the Arabic language in daily life situations, and make them able to face the challenges and difficulties in the surrounding environment whether in the classroom or outside. And the possibility of solving them easily. Therefore, it is possible to employ teaching methods related to the advanced and modern teaching strategies that deal with the practical aspect in the daily life situations experienced by the learner of Arabic language. The researcher believes that the strategy of language games is important in teaching Arabic to non-speakers, because it can provide assistance to the learner to practice language properly, to retain teaching material longer, and to be able to achieve learning more proficiently in a shorter time, associated with an increase in achievement.

The researcher noted the weakness of the non-speaking Arabic language learners within the four language skills in general, and the weakness of the ability to read especially in the beginner level at the languages center at the University of Jordan.Thus, he believes that new methods should be used to address this problem. In the same capacity, it is proposed that a study should be conducted on the impact of the use of language games in the development of reading skills among non-speaking Arabic language learners. Therefore, the study problem should be determined in the following question: What is the impact of the use of language games in the development of reading skills among non-speaking Arabic language learners in the beginner level at Languages center at the University of Jordan?

\subsection{Research Questions}

1. What are the reading skills required for non-speaking Arabic language learners in the beginner level at the Languages Center at the University of Jordan?

2. What is the impact of using language games in the development of reading skills among non-speaking Arabic language learners in the beginner level at the Language Center at the University of Jordan?

3. Is there any significant differences on the use of language games in the development of reading skills among non-speaking Arabic language learners in the beginner level at the Languages Center at the University of Jordan attributed gender (male, female)?

Based on the above, and answering the questions of the study, the following hypotheses were formulated:

The first hypothesis: There are no statistically significant differences at the level of significance $(a=0.05)$ in the development of reading skills among non-speaking Arabic language learners between the experimental and control groups due to the different method of teaching (the use of language games, the usual method). 
The second hypothesis: There are no statistically significant differences at the level of significance $(a=00.5)$ in the development of reading skills among non-speaking Arabic language learners attributed to gender (male, female).

\subsection{Purpose of the study}

The aim of this study is to investigate the effectiveness of the use of language games in the development of reading skills among non-speaking Arabic language learners.

\subsection{Study Limitations}

The results of this study are limited to the following outlines:

1. Both male and female of non-speaking Arabic language learners in the Language Center at the University of Jordan.

2. The application of language games on six lessons from the $3^{\text {rd }}$ level booklet in the beginner level at the Languages Center.

3. The application of language games on some of the reading texts presented in the booklet.

4. Adopting the study on a group of language games and on the students' achievement test.

5. Choosing the beginner level (level 3 ) as the sample of the study in a deliberate manner.

Results can be generalized to similar samples in subsequent studies.

\subsection{Operational Definitions}

Language Games: A strategy of the modern learning strategies in language learning which is carried out in accordance with certain procedures that focuses on the learner, which is the main pivot. The course is supervised by the teacher to achieve the goals that he has set in order to enhance the learner's ability to read and practice the educational position in the surrounding environment. Inan enjoyable manner accompanied by cooperation and competition among students.

The traditional method: Includes a set of teaching procedures carried out by a teacher which directly involves the teaching of reading skills for non-speaking Arabic language learners in the beginner level at the Languages Center at the University of Jordan and is based on the teacher's verbal explanation of the sub-skills to be taught according to a series of procedures based on a direct teaching strategy, in which the teacher is an interlocutor of the learning process, so that his participation remains limited while the learner receives information.

Arabic Language Learners: They are learners of foreign origin or Arab origin who have been denied the opportunity to learn Arabic and who want to learn Arabic as a second language. They are students of the beginner level at the in the Language Center at the University of Jordan and of both sexes.

Reading ability: It is the ability of non-speaking Arabic language learners within the beginner level to understand written material, the ability to convert written text into oral discourse, to understand the meanings of words and read phrases, their ability to extract and understand main and subsidiary ideas, their ability to distinguish supporting details and to simulate and employ their language skills in the proper performance of what they read. The student's performance in this skill is measured according to an achievement test prepared for that very purpose.

\section{Literature Review}

\subsection{Related Studies}

The researcher reviewed a number of previous studies conducted in the field of the impact of the use of language games in language teaching in general and in the field of teaching Arabic language to non-speakers and to develop their reading skills in particular. Since the researcher did not find any studies on the aforementioned thesis, the researcher will introduce studies on the impact of the use of language games on language teaching.

Almadanat (1993), conducted a study titled "The impact of the use of language games on the achievement of seventh grade students in conceptual reading within the post-reading phase in English language curriculum (Petra 3) aimed at investigating the impact of the title thesis compared to the traditional way. The study population consisted of all the students in the seventh grade in the Directorate of Education of the Karak -Al-Karak governorate for the academic year 1999/2001. Total students number was (2429) students.

An experimental sample representing the study population was divided into four branches; two for males and two for females with a total of (98) student were distributed to an experimental group and a randomized control group according to a lot processing levels. The experimental group studied the reading text in the second lesson of each 
unit using Languages games, while the control group studied the same lessons in the same time period during the first semester of the 1999/2000 academic year using the traditional method, a final achievement test was carried out consisting of (50) paragraphs was verified and validated. The results of the study using GAUTMA reached (88.49\%). And using (ANCOVA)it showed statistically significant differences at the level of significance $(a=0.05)$ in the arithmetic mean between the students of the experimental group who studied using languages games and the students of the control group who studied in the traditional way attributed to method of teaching for the language games strategy in the achievement of students, and there were no statistically significant differences at the level of significance $(a=0.05)$ in the arithmetic mean due to gender difference or the interaction between teaching method and gender.

The study recommended that more studies should be conducted on the impact of the use of language games in the development of language skills and the impact of their use in the teaching of the various curricula. It also recommended the need to held training courses that will encourage the use of language games. In addition to the innovation and usage of various Language games.

Liu and Chu conducted a study titled "Using games to teach listening and speaking skills in English" (2010), aimed at understanding the impact of computer games on improving listening and speaking skills among a sample of third-grade students, The results of the study indicated that there was a statistically significant effect from using the computer-based teaching strategy on improving the listening and speaking skills of students.

A study titled "The impact of the use of language games in strengthening communication skills in English as a foreign language in a sample of (1) junior students in Jordan" aimed at investigating the effect of the use of language games in enhancing verbal communication skills in English as a foreign language in the first grade in private schools. The sample consisted of (66) first grade students in one of the private schools affiliated to the Directorate of Education in Amman. They were split into two groups, one studied using language games and the other one studied using the usual method. To achieve the purpose of the study, 15 games were used to train the experimental group members on oral communication skills. Both groups underwent a test to measure oral communication skills. The results showed statistically significant differences in the use of verbal reception skills in communication situations among individuals who used language games and individuals Who did not use it for the benefit of the individuals who used it, and concluded with a set of recommendations: the need for educational games designed to serve the school curriculum and to sensitize school teachers to the importance of using language games.

Al-Nayadi (2009) conducted a study aimed at designing educational games software to identify the impact of this educational software on the achievement of the fourth grade students in the Arabic grammar in Al Ain educational city. The society consisted of (40) students of both basic and secondary stages Al-Zaher School. The sample was divided into two groups, one of which studied with the traditional way, while the other one used the educational software. To achieve the objectives of the study, the researcher designed an achievement test in the educational curricula related to the actual sentence and the nominal sentence. The results of the study showed differences in favor of the experimental group. Therefore, he recommended the use of educational games software in teaching.

Hassan (1999) conducted a study entitled the effectiveness of the use of educational games in the achievement of fourth grade students in grammar. The sample was divided into two groups. The researcher used the method of educational games in teaching the subject (the present verb) to the students of the experimental group, and used the normal method in teaching the same subject to students of the control group.The study showed that there were statistically significant differences between the experimental and the control groups for the experimental group which studied using the educational games method, the researcher recommended the use of educational games in teaching Arabic language grammar topics, and the need for it to be suitable for students' tendencies and abilities, and the need to mainstream designing language games for the rest of the other studying stages.

Densmore (1997) conducted a study aimed at explaining the impact of language games on the ability of learners to engage in dialogue, using a case study on the study sample, which consisted of two students of the first grade (male and female) and studying their social status, both were of rich background. The study applied a language game in three positions; the first was to be practiced in school and chose a language game as the instrument of the study, which is the test. The second was to be practiced in the classroom and chose a language game through classroom participation, The third position should be practiced At home he chose his language game by playing the game Monopoly. The results showed that the learners showed different changes and performances, as follows:

The first position: linguistic testing, in which the girl showed less interaction than the boy's.

The second position: Class participation, as the boy showed regular joint cooperation with the teacher, while the female student adopted repetition. 
The third position: the game of Monopoly, focused on encouragement by the family and their interest in winning. The results of the study showed the impact of learning attitudes by playing with the student's gender, cultural background and society, and recommended that games should be used in educational situations.

A study entitled "The impact of the use of a game-based program on the development of language styles and oral expression skills among fourth graders in Jordan", conducted by (Sweirki, 2004), aimed at learning the impact of the use of a language-based program in the development of language and expression skills. Consisted of (84) students from the Omar Mukhtar Primary School for Boys which reports to the Directorate of Education in the $1^{\text {st }}$ Irbid Region. The tools of the training program included eleven language games and training activities, calendar and picked language styles. The researcher applied the training program to the experimental group. The control group studied according to the prevailing method. The study sample examined the selected oral expressions in conjunction with the application of the training program.

The results of the study showed a statistically significant difference between the experimental and control groups in the acquisition of language patterns for the experimental group which studied the linguistic patterns in the language games and the positive correlation between the acquisition of the language styles and oral expression skills among the students. And the need to conduct further studies on language games in other learning cycles.

\subsection{Commenting on Previous Studies}

It is clear from the review of relevant studies and research that there is an interest from researchers in studying the impact of the use of language games in education and the impact of their use in the development of language skills. Especially in overcoming many of the obstacles and difficulties facing learners in order to help them and enable them to learn and develop their skills, which reflects positively on learning in general and on the personality of the learner in various aspects of life. The current study is consistent with previous studies and research in its attempt to identify the impact of teaching method in the development of reading skills and language learning, and it is characterized by proposing a modern educational learning strategy to be effective in Arab and non-Arab studies and research to develop reading skills among Arabic speakers. Most of the studies did not focus on the effect of the use of language games in the development of reading skill among the non-speaking learners of Arabic language, and did not carry out a similar study to the current conducting study as per the knowledge of the researcher, which made him carry out this study in order to identify the effectiveness of the impact of the use of language games in the development of reading skills among non-speaking Arabic language learners.

\section{Methods and Procedures}

This part of the study includes a presentation of its procedures, an accurate description of its members and how it was selected. It includes a description of its tools, how to prepare them, and verifying their validity, consistency, procedures and statistical processes used to analyze their results.

\subsection{Study Approach}

The researcher used a quasi-experimental method, which was based on two experimental and control groups, and also for its convenience with the purpose of the study.

\subsection{Study Members}

The study population consisted of (40) educated Arabic language learners in the beginner level at the Languages Center at the University of Jordan. The two study groups were tested and distributed randomly. The experimental group consisted of (20) educated person, and the control also consisted of (20) educated person.

\subsection{Study Tools}

To achieve the objectives of the study, the researcher prepared a tool for testing reading skills, after reviewing the discipline of educational research and the previous theoretical literature on reading skills in the Arabic language for non-speaking Arabic language learners and the codex for Arabic teachers, such as: (Al-Fozan, 1430, AH) and (HabibAllah, 2000) (Rushdi, et al, 1984) and (al-Naqa, 2003).

In addition to the researcher's long experience as a university professor in the field of teaching Arabic language to non-speakers in many Arab universities, he took the views of teachers of Arabic language for non-speakers and teachers of Arabic language curricula for non-native speakers and methods of teaching. The research was prepared in the final form of (20) sub-skills which the test will be marked accordingly.

\subsection{Validity and Reliability of the Test}

To verify the validity of the test, it was presented to nine arbitrators specialized in the field of teaching Arabic to non-Arabic speakers, specialists in the field of Arabic language curricula, teaching methods and experts in the 
writing curricula and methods of teaching in Jordanian universities. They were asked to express their views on the validity of its paragraphs and its relevance to the educational material in terms of Content and wording, and to add, edit or omit as they deem appropriate. In order to verify the veracity of the list of reading skills prepared by the researcher, it was presented to nine arbitrators specialized in the field of teaching Arabic to non-speakers and specialists in the field of Arabic language curricula and teaching methods and experts in the formulation of curricula and methods of teaching, and asked them to express their opinions in terms of their suitability for nonespeaking Arabic learners at the beginner level and the integrity of its formulation, and the appropriate distribution of marks and requested To add or delete what they deemed appropriate, and also to make their observations in the light of their educational experience. The text of the list was presented in its final form. It also presented educational texts at the introductory level, which taught the strategy of language games to specialists, experts and professors in the field of language games, its teaching and teachers of educational technology, in order to referee them in the style of language games. They were also asked to submit their notes either in omitting or editing, and adjustments were made in accordance with their views.

To ensure that the reading test was stable by applying and re-applying, it was submitted to an exploratory sample from outside the sample of students from the junior level of the non-speaking Arabic language learners. Pearson correlation coefficient was extracted between the two test applications in each reading skill. After analyzing the data of the sample of the survey sample and the data of the individual survey sample, the stability coefficients of reading skills $(0.678)$ was extracted. These parameters are considered suitable for the purposes of this study.

\subsection{Test}

The reading skills test included the following items:

1. The researcher met with teachers of Arabic language for non-speakers to determine the number of weekly hours to teach reading skills, in (8) hours per week, two hours a day for four days.

The researcher built two tests: pre-test and post-test for reading skills in order to verify the parity of the experimental and control groups, and to find out to what extent the Arabic language learners were able to read skills in the non-speaking beginner level booklet.

\section{Characteristics of reading test paragraphs}

The difficulty coefficients, and the discrimination of the test paragraphs, were extracted after application on the exploratory sample, and Table (1) shows this.

Table 1. Values of difficulty and discrimination coefficients for reading test:

\begin{tabular}{cccccc}
\hline Paragraph No. & $\begin{array}{l}\text { Difficulty } \\
\text { coefficient }\end{array}$ & $\begin{array}{l}\text { Coefficient of } \\
\text { discrimination }\end{array}$ & Paragraph No. & $\begin{array}{l}\text { Difficulty } \\
\text { coefficient }\end{array}$ & $\begin{array}{c}\text { Coefficient of } \\
\text { discrimination }\end{array}$ \\
\hline 1 & 0.33 & 0.33 & 11 & 0.43 & 0.39 \\
2 & 0.61 & 0.61 & 12 & 0.63 & 0.52 \\
3 & 0.51 & 0.51 & 13 & 0.59 & 0.41 \\
4 & 0.41 & 0.41 & 14 & 0.43 & 0.40 \\
5 & 0.40 & 0.40 & 15 & 0.38 & 0.43 \\
6 & 0.60 & 0.60 & 16 & 0.49 & 0.54 \\
7 & 0.39 & 0.39 & 17 & 0.56 & 0.39 \\
8 & 0.44 & 0.44 & 18 & 0.55 & 0.46 \\
9 & 0.41 & 0.41 & 19 & 0.48 & 0.55 \\
10 & 0.37 & 0.37 & 20 & 0.44 & 0.50 \\
\hline
\end{tabular}

Table (1) shows that the values of the difficulty coefficients for the reading test ranged from $(33.0-63.0)$. While the values of the coefficient of discrimination between $(0.55)$ and these values are suitable for the purposes of the current study.

\section{Correct reading test}

The test shall be of (20) paragraph distributed on reading sub-skills. The grades were given from (0-5) so the greatest value of reading skill will become (100) and the smallest value (zero). Accordingly, the arithmetic average of reading skill $(0-100)$ is modified. 


\section{Study Procedures}

To achieve the objectives of the study, the researcher conducted the following steps:

1. Identification of students from the beginner level in the Language Center at the University of Jordan.

2. Review literature and previous studies on the impact of using language games in teaching Arabic in general and teaching languages.

3. The researcher met with teachers of Arabic language for non-speakers concerned with the implementation of the experiment. He trained them to teach the strategy of language games and introduced them to the necessary procedures for this strategy and how to implement the teaching effectively within the classroom, with the explanation of the concept of language games and its philosophy and its importance in developing reading skills among non-speaking Arabic language learners and developing the other four language skills, the types of educational language games and how to use them, and provided them to all the teachers.

4. Provide the teachers with the analysis of the content of the modules, the preparatory notes for each lesson, the identification of the general and specific lessons of the lessons, and the preparation of a list of the general and special productions represented by each educational language game.

5. To enrich teachers' knowledge of the texts that are appropriate to the language games and the way they are implemented, and to prepare educational texts based on language games and to match the reading skills of the Arabic language learners with other speakers.

6. Conducting a process of matching the subjects of texts in the Arabic language book to non-Arabic speakers to teaching texts dealing with language games, and preparing a guide for the teacher on the strategy of language games and teaching texts.

7. Arbitration of the language games by presenting them to a group of specialists in the field of teaching the language games and the field of teaching the Arabic language to non-speakers, and asking them to express their opinions and observations by deleting or adding and judging the extent of the game suitable for novice students and indicating the possibility of covering the desired products and objectives.

8. Arrange a meeting with the students of the experimental group that includes males and females, and guide them, and explain how to work through the strategy of language games in a simplified manner commensurate with their educational level and urged them to cooperate with their teachers, and training students to perform the game language. The language games included a series of activities in a meaningful and fun way for the students to know their idea and what it contains and how to perform it under the supervision of the teachers. The students were divided into five groups in each group. Three students ranged from different levels according to the achievement levels in the center Languages, previously obtained by the student.

9. Continue the process of the experiment effectively with the teachers, and the extent of interaction of students during their learning strategy games language.

10 - Preparation of pre - test and post - reading skills to verify the parity of the experimental and control groups. The test of reading skills was presented to a group of specialists in the field of teaching Arabic to non - Arabic speakers and specialists in the field of Arabic language curricula and teaching methods. To the extent that they are appropriate and have taken their notes and opinions.

11. For the purpose of ensuring the stability of the test, twice a time interval was applied to an exploratory sample of Arabic language learners for non-native speakers at the novice level. The correlation coefficients between the two applications were calculated and the consistency coefficients were acceptable for the purposes of the study.

12. The application of reading skill test on the experimental and control groups before the start of the strategy of language games and the collection of grades of students on the reading test, and the necessary statistical treatments, and the results showed no differences between the two groups or any differences attributed to the variable sex, indicating the existence of parity between them.

13. Implementation of the strategy of language games on the learners of Arabic language for non-speakers in the experimental group, and contain the language games on some of the accompanying activities.

14. Teaching the control group according to the usual method and the same texts that were taught to the experimental group.

15. Apply the test to the two groups: experimental and control.

16. The introduction of data into the computer by the statistical program (SPSS) of human sciences and processing using the statistical averages and standard deviations, and statistical comparisons between them to verify the 
hypothesis of the study, and the extraction of results and discuss and make recommendations for the study.

\section{Results}

Results related to the first question: What reading skills are required for learners of Arabic language for non-native speakers at the beginner level in the Languages Center at the University of Jordan?

In order to answer this question, the previous pedagogical literature related to the reading skills required for nonspeaking learners of Arabic language was revisited at the beginning levels. The aim was to identify the reading skills of the Arabic language learners, in addition to research, scientific conferences and training courses in this field, such as: (Madkour et al, 2014), (Fawzan, 1430, AH) (Habiballah, 2000 ) (Rushdie et al, 1984), (Muhammad Kamel al-Naqa,) ( Rushdi, 2003). The researcher came up with a list of reading skills needed for non-speaking learners of Arabic language in the beginner level in the Language Center at the University of Jordan level, as shown in the table (2).

Table 2. List of reading skills required for non-speaking Arabic language learners at the beginner level in the Languages center at the University of Jordan

\section{No. Reading skills}

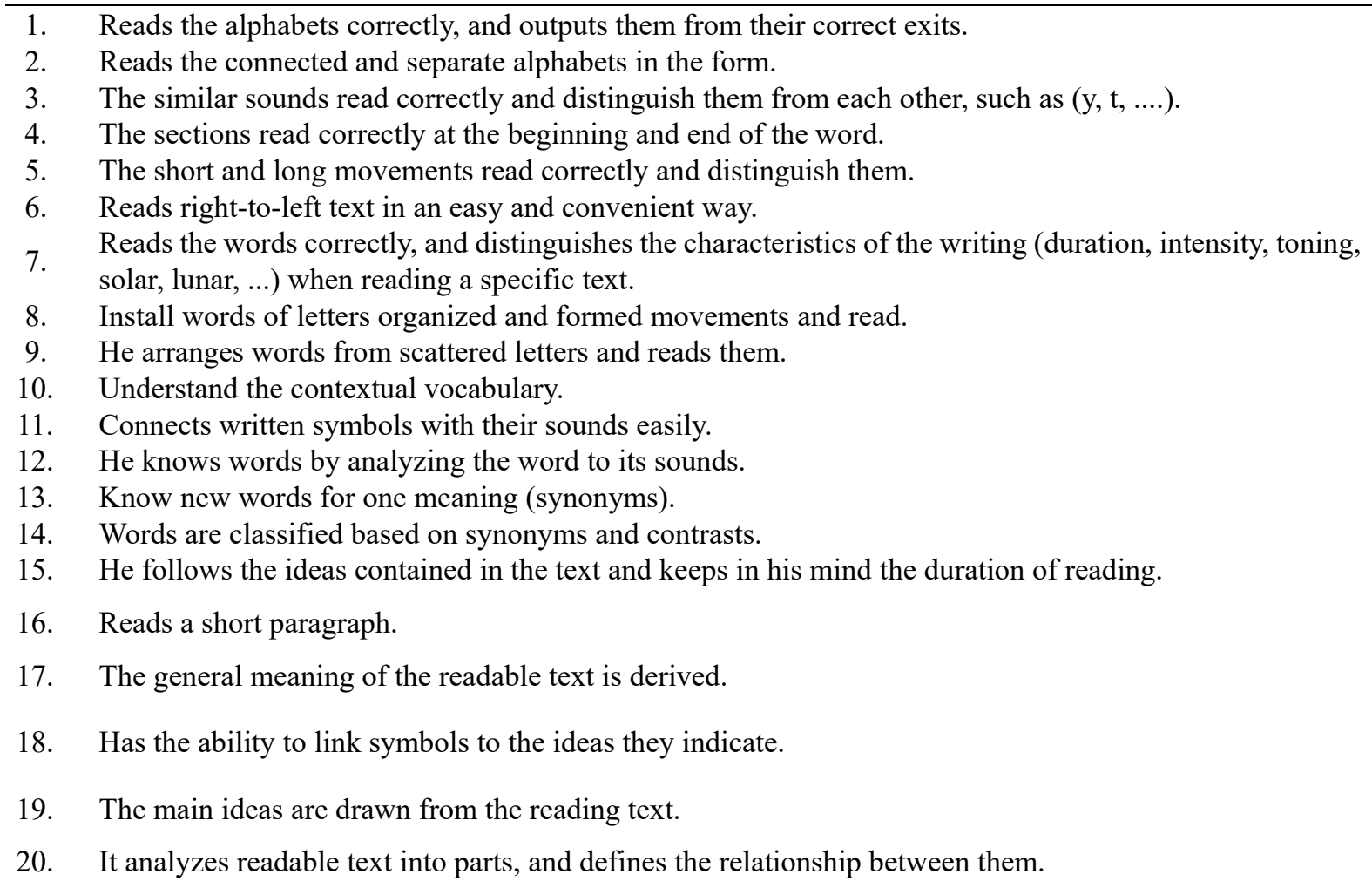

Question 2: What is the impact of using language games in developing reading skills among Arabic language learners of non-native speakers at the beginner level in the Language Center at the University of Jordan? The following study hypothesis emerged stating that there were no statistically significant differences in the level of significance $(\mathrm{a}=0.05)$ in the development of reading skills among the non-speaking Arabic language learners between the experimental and control groups due to the different method of teaching (using of language games, The normal method).

In order to answer this question, the experimental group was taught according to the method of language games and the control group taught according to the traditional method. After the completion of the processing, the researcher conducted a post-test to measure and observes the effect of treatment on their marks obtained of the post-test. The mean and standard deviations of the control and experimental students were calculated on the posttest and compared with the pre-test as shown in Table (3). 
Table 3 .

\begin{tabular}{lllll}
\hline \multicolumn{1}{c}{ Test } & \multicolumn{2}{c}{ Control group } & \multicolumn{2}{c}{ Experimental group } \\
\cline { 2 - 5 } & Arithmetic mean & $\begin{array}{l}\text { standard } \\
\text { deviation }\end{array}$ & Arithmetic mean & \multicolumn{1}{c}{$\begin{array}{c}\text { standard } \\
\text { deviation }\end{array}$} \\
& & & & \\
Pre-test & 0.4281 & 0.637 & 0.4121 & 0.711230 \\
Post-test & 0.3306 & 0.07065 & 4.3188 & 0.27349 \\
\hline
\end{tabular}

Table (3) indicates that the arithmetic average of the control group students was (428.1) on the pre-test test. For the experimental group, the arithmetic mean was 412.1 in the pre-test, indicating the equivalence of the two study groups.

The table also indicates that the mean of the students in the control group reached (306.3) on the post-test, with a standard deviation of (7065.0). The arithmetic mean of the experimental group reached (3188.4) in the post test indicating a significant improvement in the grades of students who were subject to thestudy. The standard deviation of the experimental group (27349.0) indicates a civil dispersion in the responses to the experimental group of the post-test.

When comparing the results of the students' performance to the experimental and control groups in the pre and post-tests, there was an increase in the arithmetic averages for the experimental group, which increased by (9068.2) than in the pre-test. In the control group, the arithmetic average of the students' performance increased by $(878.1)$ it is in the post-test.

The hypothesis of the following study indicates that: There are no significant differences at the level of significance $(\mathrm{a}=0.05)$ in the development of reading skills among non-speaking Arabic language learners between the experimental and control groups due to the different method of teaching (use of language games, the usual method).

To determine whether these differences were statistically significant, the Paired Samples Test was used. Table 4 indicates the results of the test:

\begin{tabular}{|c|c|c|c|c|}
\hline Group & $\mathrm{t}$ & $\mathrm{df}$ & T tabular & $\begin{array}{l}\text { Level } \\
\text { significance }\end{array}$ \\
\hline Experimental & 14.551 & 39 & 2.042 & 0.00 \\
\hline
\end{tabular}

Control

Table (4) indicates that the calculated value of $t$ is 551.14, which is higher than its tabular value and at a statistical significance level of (000.0), which is less than the estimated value (0.05) indicating statistical presence, indicating differences Statistical significance for the experimental group in reading skills.

Results related to the third question: Are there differences in the use of language games in the development of reading skills among non-speaking Arabic language learners at the beginner level in the Language Center at the University of Jordan due to gender (male, female)?

The following hypothesis emerged from this question, stated that there are no statistically significant differences at the level of significance $(=0.05)$ in the development of reading skills among non-speaking Arabic language learnersat the beginner level in the Language Center at the University of Jordan is due to gender.

In order to test the hypothesis of the second study, the one-way ANOVA test was conducted for the existence of statistically significant differences at the level of (0.05) in the development of reading skills among non-speaking Arabic language learners.

Table 5. ANOVA Analysis of differences in the development of reading skills among non-speaking Arabic language learners. (Male, Female):

\begin{tabular}{lllllll}
\hline & Total squares & $\begin{array}{l}\text { Degrees } \\
\text { freedom }\end{array}$ & of & $\begin{array}{l}\text { Average } \\
\text { squares }\end{array}$ & F value & $\begin{array}{l}\text { Statistical } \\
\text { significance }\end{array}$ \\
\hline SEX & $\begin{array}{l}\text { Between } \\
\text { groups } \\
\text { In groups }\end{array}$ & .13233 & 24 & .247 & .0381 & .442 \\
& .25015 & 15 & .238 & & \\
\hline
\end{tabular}


It is clear from Table (5) that there are no statistically significant differences in the development of reading skills among non-speaking Arabic language learners. The gender is $\mathrm{f}(038.1)$, which is less than the tabular value of 68.2 at a level of (442.0) (05.0), indicating no significant differences.

In other words, there is no statistically significant effect at the level of significance (a 0.05 ) in the development of reading skills among Arabic speakers of non-Arabic speakers.

\section{Discussion of the Study Results}

Results related to the first question: What reading skills are required for non-speaking Arabic language learners at the beginner level at the Language Center at the University of Jordan?

To answer this question, the previous pedagogical literature on reading skills for Arabic and non-Arabic learners was revisited at the beginning levels. The aim was to identify the reading skills of Arabic language learners, as well as research, scientific conferences and training courses in this field and to conduct direct interviews with beginners Language Center at the University of Jordan and teachers of Arabic language for non-Arabic speakers in other language centers and institutes in addition to the researcher's long experience in this field, as well as previous studies conducted in this field. (Habiballah, 2000), (al-Naqa \& Rushdi, 2003), where the researcher reached a list of reading skills (Madkour et al, 2014) For non-speaking Arabic language students at the beginner level at the Language Center at the University of Jordan, as shown in Table (2).

Results related to the second question: What is the impact of the use of language games in the development of reading skills among non-speaking Arabic language learners at the beginner level in the Language Center at the University of Jordan?

The following hypotheses emerged from this question, which stated that there are no statistically significant differences at the level of significance $(\mathrm{a}=00.5)$ in the development of reading skills among non-speaking Arabic language learners between the experimental and control groups due to the different method of teaching ( The results of the study showed statistically significant differences at the level of significance $(a=0.05)$ due to the effect of the use of the language games strategy compared to the traditional method. This may be due to the following reasons:

1. The strategy of language games is one of the new strategies in teaching languages, and it is new to the learners because everything that is new inspires in students the love of learning and increases their motivation and eagerness to know new things. The researcher noticed that the students enjoyed learning according to the strategy of Language games, so that they were placed in everyday life situations and were able to practice reading skills, knowledge of their contents and what is going on in their orbit, and they have tried and applied according to goals and attitudes studied and planned based on scientific foundations.

2. The strategy of language games has helped to inspire learners to be more creative and thoughtful, to become more receptive to learning reading skills, to actively accept their practice, and to increase their enjoyment, which generates love and desire to practice.

3. The language games strategy for each learner has enabled learners to be active participants in the application of daily life situations andto use of what they have learnt in the classroom and apply it in educational situations away from traditional teaching methods, so that each learner interacts with other learners through the expression of his views, which increased their sense of responsibility and reduced their shyness, and helped to facilitate the learning of reading skills.

4. Students' team-work in the implementation of language games helped them to feel enjoyed and happy, which led them to learn more quickly, and to become keener to the teacher and to learn reading skills. This will help them to develop their other language skills and increase their academic achievement.

5. The strategy of language games has contributed to the activation of the processes of thinking and creativity in the educational learning process, through student's self-interaction, thinking and creativity in educational situations.

6. The strategy of language games included many different language games that contributed to the increase of participation from learners in the games and the accompanying learning activities, which aims to enhance the student's ability to distinguish between characters and compare them to another, and helps to increase their concentration in the text reading, and helps students to master reading of letters and sections, reading words, sentences, phrases and paragraphs, developing analytical skills and other reading skills. 
Discussion of the results related to the third question: Is there an effect on the use of language games in the development of reading skills among learners of Arabic language for non-native speakers at the beginner level at the Language Center at the University of Jordan for sex (male, female)? The following hypothesis emerged from this question, which states that there is no statistically significant effect at the level of significance $(a=05.0)$ in the development of reading skills among the Arabic language learners of other speakers. The results of the study presented in the above showed no significant difference The researcher attributed the reason for the lack of differences in the development of reading skills among the Arabic language learners of non-Arabic speakers due to gender (male, female) due to the following reasons: (1)

1. Approaching the achievement levels that were accepted on the basis of the beginning level of the language center, the classification test for non-speaking Arabic language learners held by the Center at the beginning of each semester,

In particular, these students have passed the exam. This also demonstrates the convergence of the language skills of the Arabic language learners of non-native speakers, both male and female, who have the ability to practice and employ them.

2. The educational environment is similar to male and female learners, and environment conditions are similar in both inside and outside the university, and teacher's abilities who implemented the educational process and the methods, activities, games and tools are all equal.

3. The similarity of the strategies and teaching methods offered by the non-speaking Arabic language learner's teachers in the Language center.

4. The similarity of textbooks taught at the beginner level in the Language Center.

5. Equal opportunities for non-speaking Arabic language learners, whether male or female.

\section{Recommendations}

In light of the results of this study, the researcher recommends the following:

1. Activate the strategy of language games as one of the modern and effective educational strategies in the teaching of reading skills and other language skills amongnon-speaking Arabic language learners.

- Convene training courses and workshops fornon-speaking Arabic language teachers to familiarize them with the strategy of language games and their importance in the development Arabic language skills and in teaching the Arabic language to non-native speakers.

- The need to use the strategy of language games in the curricula of teaching Arabic to other speakers.

- The need to produce a variety of language games to teach the 4 Arabic language skills to non-speakers (listening, conversation, reading, writing), and linguistic elements that contribute to the development of language education.

- Conduct more studies to identify the impact of the use of language games in the development of other language skills, and on intermediate levels of education and other Arabic teaching institutes for non-native speakers, and on more samples in different universities.

- Adopt the list of reading skills in the beginner level privileged in the current study on the programs of teaching Arabic in centers and institutes dedicated for non-native Arabic speakers.

- Draw the attention of the authors of the Arabic language curricula to to the importance of language games strategy and to the need to include it in some of the curriculum as a meaningful educational lessons accompanied by a teacher's guide to show how to use them.

\section{References}

Abdo, R. (1993). The Effect of Using Language Games in Strengthening Communication Skills in English as a Foreign Language in a Sample of Jordanian Junior Students, Unpublished Master Thesis, Graduate School, University of Jordan, Amman, Jordan.

Al-Fawzan, Ab (1430H), Specialist, Illuminations to improve the efficiency of teachers of Arabic for non-native speakers, Arabic for All, Riyadh, Saudi Arabia.

Almwajeh, M. O., \& Rababah, L. (2018). Literature is the best tool of awaking moral understanding and evaluation: Wendell Berry's the Long-Legged House. Journal for Translation \& Literary Studies, 2(2), 69-80. https://doi.org/10.24093/awejtls/vol2no2.5

ALRababah, I., \& Rababah, L. (2019). The Use of Brainstorming Strategy Among Teachers of Arabic for Speakers of Other Languages (ASOL) in Writing Classes. International Journal of English Linguistics, 9(1), 15-24. 
https://doi.org/10.5539/ijel.v9n1p15

BaniKhlaf, A., \& Rababah, L. (2018). Gender differences and emotional expressiveness on Facebook: An analysis of prosodic features among Jordanian facebookers. Studies in Linguistics and Literature, 2(3), 180-194. https://doi.org/10.22158/sll.v2n3p180

Densmore, A., E., (1997). A Different Language Game Un published Doctoral Dissertation, University of California, Irvine.

Habibullah, M. (2000). The Foundations of Reading and Understanding between Theory and Practice, introduction in developing Understanding, Thinking and Learning Skills, Amman, Petra Market, Amman, Jordan.

Hussein, H. (1999). The effectiveness of using educational games on the achievement of fourth grade Students in Grammar Teaching. Faculty of Education Journal, 15(1), 1-15. http://dx.doi.org/10.13187/ejced.2016.15.94

Jdaitawi, T., Ishak, N., Taamneh, A., Gharaibeh, N., \& Rababah, M. (2011). The effectiveness of emotional intelligence training program on social and academic adjustment among first year University students. International Journal of Business and Social Science, 2(24). http://dx.doi.org/10.5539/ijps.v3n2p135

Liu, Y., \& Chu, Y. (2010). Using ubiquitous games in English listening. Journal of General Linguistics, 3 (1), $20-$ 35. https://doi.org/10.1016/j.compedu.2010.02.023

Madanat, H. (1993): The impact of the use of language games on the achievement of seventh grade students in conceptual reading within the post-reading phase in English language curriculum (Petra 3), Unpublished Master Thesis, Faculty of Education, Mutah University, Jordan.

Madkour, Ali. (2010), Reference in teaching Arabic to speakers of other languages. Dar Al Fikr Al Arabi, CairoEgypt.

Rababah, I., \& Rababah, L. (2017). Investigating Arabic to Speakers of Other Languages (ASOL) Lecturers' Attitudes towards Utilizing Flipped Classroom Instruction (FCI): A Qualitative Study at Jordanian Public Universities. International Education Studies, 10(7), 94-104. https://doi.org/10.5539/ies.v10n7p94

Rababah, L. (2018). An adapted version of Torrance test of creative thinking (ttct) in efl/esl writing: a rubric scoring and a review of studies. International Journal of English and Education, 7(2), 128-136.

Rababah, L. M., Mohamed, A. H. Bin, Jdaitawi, M. T., \& Melhem, N. Z. B. (2013). The level of creativity in English writing among Jordanian secondary school students. Arts and Design Studies, 10, 25-29.

Rababah, L., \& Almwajeh, M. (2018). Promoting creativity in EFL/ESL writing through scaffolding strategy. International Journal of English and Education, 7(3), 148-160.

Rababah, L., \& Melhem, N. (2015). Investigation into Strategies of Creativity in EFL Writing in Jordan. Journal of Literature, Languages and Linguistics, 3(5), 14-25.

Rababah, L., Alshehab, M., \& Melhem, N. Z. B. (2018). Exploring the Factors that Hinder Jordanian Students in Developing Creativity in EFL Writing. International Journal of English and Education, 7(3), 161-170. https://doi.org/10.17758/EIRAI.F0117427

Rababah, L., Bani-Melhem, N., Jdaitawi, M., Rababah, B., \& Rababah, O. (2012). EFL teachers' barriers to the use of ICT in instruction in Jordan. In Proceedings of the 1st International Conference on Behavioural and Social Science Research (ICBSSR) (pp. 1-5).

Shafi, N. (2009). The Impact of Educational Software on Fourth Grade Students Achieving inArabic Grammar in Al Ain Educational Zone, United Arab Emirates, Unpublished Master Thesis, United Arab Emirates University, Abu Dhabi, UAE.

Taaima, R., \& Naqah, M. (2006). Teaching the Language of Communication between Curricula and Strategies. ISESCO publications - Rabat - Morocco.

The Islamic Educational, Scientific and Cultural Organization (ISESCO). (2006). Arabic Language to Where, Publications of the Islamic Educational, Scientific and Cultural Organization (ISESCO), Rabat, Morocco.

\section{Copyrights}

Copyright for this article is retained by the author(s), with first publication rights granted to the journal.

This is an open-access article distributed under the terms and conditions of the Creative Commons Attribution license (http://creativecommons.org/licenses/by/4.0/). 